departments, faculty members insist on each doing their own course planning, choosing times and subjects independently. This forces the administration to revise courses to ensure that the credits assigned to each are consistent, that students have taken the prerequisites the professors require, and that everything is presented in the format that the computer system recognizes, so that students can register online. Although this may sound like part of administrators' responsibilities, the job can be so big that one department Marty worked with had to dedicate two full-time staff members to resolving such conflicts. Yet academics often grumble at the resources their universities devote to administration.

If scientists truly value their autonomy, they must let go of the traditions that cause more harm than good to the research enterprise. According to Paula Stephan, on page 29, these traditions are often tied to counterproductive financial incentives, such as a US government accounting rule that allows universities to use debt from new construction to increase the indirect rate that they add to grants for overhead costs. This encourages universities to constantly expand rather than house researchers in buildings they already own, and creates an idea that bigger is always better. But, in biomedical sciences, bigger labs have not been associated with a substantial increase in output, and the economic downturn means "the building boom is now costing the scientific enterprise by creating excess space that cannot be paid for", says Stephan.

Scientists may bristle at some of the suggestions proposed to improve the efficiency of the research enterprise. Run academic institutions more like private businesses? Increase the power of institute directors and university presidents so they can make more executive decisions without asking for faculty members' input? Place a 'tax' on the use of temporary workers such as graduate students and postdocs, to encourage scientists to hire more permanent staff scientists?

But scientists should think twice about this instinctive, defensive approach. Something that may seem a threat to academic autonomy is often quite the opposite. A standard template for course planning that all faculty members must adhere to, for example, with strict deadlines for each phase, could cut the number of course revisions. This would free staff to deal with other administrative issues, letting the scientists who had been shouldering that burden get back to research and teaching. Similarly, every 16-person committee that meets once every 2 months

"Something that may seem a threat to academic autonomy is often quite the opposite." for 4 hours can amount to as much as 100 labour days per year, when other costs such as preparation time and staff support are taken into account. Although giving leaders more power to make executive decisions without consulting faculty members may seem to threaten academic independence, in this instance giving up decision-making powers allows scientists to spend more time doing creative, independent research.

And if scientists truly value their power and independence, they must lead the discussion over what works in the research enterprise - and what doesn't. If they don't, someone else will make those decisions for them, by imposing even more funding cuts that directly hurt research and teaching. Scientists cannot continue to live by the double standard that Pierre Azoulay recognizes on page 31, applying deep scepticism to scientific data but unquestioning faith to the practice of science itself. They must approach suggestions to improve academic efficiency with an open mind, trying some and noting whether any impinge on their creativity. However, if implemented properly, none of the suggested changes should have any impact on scientists' all-important academic freedom. If we strengthen the system that supports it, science can only thrive.

\section{Into the depths}

\section{Celebrity missions to the deep ocean won't make up for cuts to marine science.}

L ast week, depending on your point of view, film director James Cameron either made history or reached a new low. In descending to the deepest part of the ocean, Cameron became the first human to make a solo visit to the Challenger Deep, nearly 11 kilometres from the surface. He is only the third person ever to make such a dive (see Nature http://doi.org/hsj; 2012).

Cameron's mission mostly failed in its scientific ambition to recover samples. Equipment failure allowed his submersible to bring back just one piece of sediment and no rocks. But his team has pledged to make further dives, and although there may be no large creatures lurking at that depth, the opportunity to analyse the microorganisms likely to be found in the sediment is unprecedented.

Congratulations flooded in from around the world, many from marine scientists. Among those to send good wishes was the UK National Oceanography Centre (NOC).

But a week that started brightly for the field ended less well. Although Cameron was inspiring the next generation of marine scientists on Monday, by Wednesday news was reaching Nature that the NOC was shedding nearly one-quarter of its scientific staff, based at sites in Southampton and Liverpool (see Nature http://doi.org/hsk; 2012).

This is partly a response to Britain's financial woes, which have kept down or cut budgets at the country's research funding councils in recent years. But the centre's problems have been exacerbated by the stance of the UK Natural Environment Research Council (NERC) — which provides most of the NOC's funding and has decided to "gradually shift the balance of science funding from long-term survey, monitoring and infrastructure such as ships towards front-line, competitively awarded, strategic environmental research", it said in a statement.

The upshot is that 35 posts are to be lost in the NOC's science section, as the centre attempts to make savings of $£ 3.5$ million (US $\$ 5.6$ million) a year on its $\mathfrak{£} 45$-million annual budget.

Ocean researchers around the world have been devastated by the news of the cutbacks, which jeopardize a number of international collaborations in areas such as climate and ocean modelling.

NERC insists that the NOC will still be a major player in the field, albeit "with a somewhat leaner, but even more highly competitive scientific team". But researchers fear that this focus will threaten projects that gestate slowly, which have until now been highly valued.

In the United States, too, researchers have reason to fret. Budget negotiations can be tortuous, with nothing set in stone until the final vote, but there is growing concern about the future of the National Undersea Research Program (NURP). The programme, run by the US National Oceanic and Atmospheric Administration (NOAA), hosts much of the country's research fleet of scientific submersibles. Other NOAA programmes are also under scrutiny.

When the costs of high-profile glamour projects such as manned space flight draw criticism, supporters often say that their publicengagement value offsets mission costs. With Cameron's dive, science got a freebie. No government funds that could have gone to austerityhit research labs were used: this was one man doing what he wanted with his own money. Others with similar means are set to follow Cameron into the deep, and wealthy individuals are likely to reach space under their own steam and on their own terms in the near future.

But will science be well placed to exploit the massive appeal of Cameron's dive and the new attention that will be given to the ocean depths? Scientists have sent unmanned vehicles to the Challenger Deep between the manned mission in 1960 and last week's visit. Those $\rightarrow$ NATURE.COM To comment online, click on Editorials at: go.nature.com/xhunqv trips were made with kit that relies on the skill and dedication of scientists working for programmes such as NURP and the NOC. While Cameron celebrates, ocean science slips a little further out of reach for everyone else. 